度が適切か，又しかなる感光材料を用い画質の低下なく 被曝をへらして検查出来たかを報告した。

\section{5. 排泄性胆のう造影への傾斜断層の適応}

日本医科大学附属病院放射線科

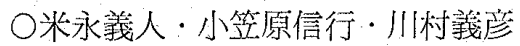

鈴木 消 石田勝战

排泄性胆のう造影の総胆管末端部における傾斜截断面 の適応を检討した。使用装犆はプリンセプス60放もちい た。総胆管の傾斜は腹卧位において $33 \%$ 程度，末端部が 低いがその角度は一概に定まらなかった.実験では，ビ リグラフイン希釈液封入チューブを傾斜 $\left(45^{\circ}\right)$ し，截断 面傾斜を $25^{\circ}$ まで変化させて，像現出の違いを求めた。 結果, 模擬胆管の走行 (平行から $45^{\circ}$ 屈曲)，之，傾斜截 断面角度の正礁な一致をみなくとも，近似した角度で， しかあ截断尿に入れば良しとしが知れた。臨床军真での 倹討結果では，未端部の低り $10 \sim 15^{\circ}$ 傎斜截断面で水平 截断面より優れた像を得た。今後の利用方法としては， 水平截断面汃らの精密検査としての適応加考えられる。

26. 胸部 $\mathrm{X}$ 線撮影における希土類增感紙と $\mathrm{CaWO}_{4}$ 系増 感紙の比較検討

化学療法研究所附㾖病院 林 太即 千等大学放射線技師学校，酒牪淌信 都立駒込病院 ○坂野厤昌

\section{質問}

希土類堌感紙の致命的な欠陌は，粒状性の琹さにある 之思われるが，(1)物理的粒状性について，RMS 值など 物理的実験はおこなったか？その結果は $\mathrm{CaWO}_{4}$ との 比較值はどうであったか?

(2) 心理的評価はおとなったか，MR-400とLH-IIの MTF は，活汪同じと思われるが，実際の臨床等真はあ きらかな牛があると琶われるが，どうか？

(3) 胸部X線写真のような微細な病変をおうものに対 して，䊀状性の悪さは障害院影とならないのか？

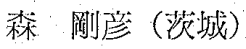

\section{答}

心理的粒状性と物理的粒状性との一致が理想であるが， そこには大きな溝が殿然と存する。

そこで，物理的数值を実験值加ら導人して，理的な ものの聾づけとしようと企画し，実験を行ない，加つ， X線写真を䀢師に読影してもらい，読影上支障をきたさ ないか否かを判断してもらった。その事により上誁の理 想に近つくような結果が得られた。

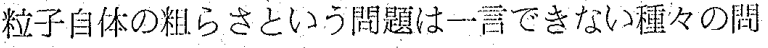
題を含むと䄈えます。
27. $105 \mathrm{~mm}$, I.I. 間接 BI-PLANE の画質改善について 筑波大学附属病院放射線部

○小沼武雄・小鴨義尚・松野博志

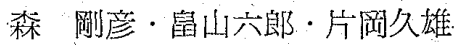
村松恵三 ·加藤利一 - 平田雅洋 江橋敏男

今回当大学化，脈管撮影用として，Biplane，105 mm， I.I. 間接を設置した。しかし，I.I.によるBiplane 撮影 は，I.I. が screen と比較して非常に高い感度を持つ為， 側方散乱線によるカブりが多く，画質を非常にわるくす

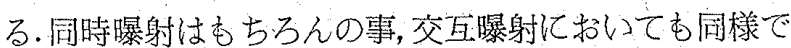
ある. そこで画質を改善すべく I.I.にブランキングをか けた.ブランキング即ち，バイプレインを交互曝射で動 かし，一方が撮影している時は，もう一方のIII. の集束 電压をプラスにし，像を結ばない様にします。このブラ キングという操作によって画質，主にカブリを大幅に改 善する事ができた。

\section{質問}

プランキングさせている最小追従時期（分解時間）乙 高速撮影 (シネ撮影) 飞使用可能か?

木村 (神漈川)

\section{答}

I.I.の分解能（瀷度の立上りの意味）は実際に測定し ていませんが，輝度の残像的なむのはフィルム上では全 く見とめられません。cine 亿関しましては検訶していま せんが，スピードが早い為困難さがある様に思います。

\section{8. スキャノグラフィの放射線治療への応用}

国立松本病院放射線科 常田長時

放射線治療装置に比ベシミュレー夕の普及は極めて低 い（佥野罧下では10施設中一台），末設犆施設での照射 野設定精度の向上について検討した。

[方法]

一般透視装犆による透視下撮影とCo-60 治潦葠台を 移動撮影可能に政良 3 方向のスキャノグラフィをえた。 〔結果・考察〕

. 任意の 2 方向移動を組会せるととにより，写体の平面， 側面は横断面の害大像がえられる。

従来の写萁比較計測の方法より愦差が少なく，また， 外部標識と深部との相刘関係が確保できるなど有効であ った。桩大辣表示法の統一など投影像の解析，教育と装 置の性能管理の充実方望まれた。今後スキャノグラフィ の活用面について検討したい。

質問

治療台の改造㙺は。 